\title{
The modular structure of the floral phenotype in Mimulus luteus var. luteus (Phrymaceae)
}

\author{
Estructura modular del fenotipo floral en Mimulus luteus var. luteus (Phrymaceae) \\ GASTÓN CARVALLO* \& RODRIGO MEDEL \\ Departamento de Ciencias Ecológicas, Facultad de Ciencias, Universidad de Chile, Casilla 653, Santiago, Chile; \\ *e-mail for correspondence: endorfina@netexplora.com
}

\begin{abstract}
Most studies of multivariate evolution on the floral phenotype assume that traits evolve independently one from each other, ignoring the modular structure that results from genetic correlations or developmental constraints. In this paper we describe the interdependence of nine floral traits in the herb Mimulus luteus var. luteus (Phrymaceae), as an attempt to characterize functional modules on which natural selection can potentially act upon. Using edge exclusion deviance analysis, we detected four modules: (a) an attractiveness module, (b) a stigma behavior module, (c) a stigma surface module, and (d) a herkogamy module. Consequences of these findings for future studies of natural selection in this species are discussed.
\end{abstract}

Key words: correlational evolution, edge exclusion deviance, phenotypic integration, plant-pollinator, interaction, selfing avoidance.

\section{RESUMEN}

La mayor parte de los estudios de evolución multivariada sobre el fenotipo floral suponen que los rasgos evolucionan independientemente unos de otros, ignorando la estructura modular que resulta de correlaciones genéticas o restricciones impuestas por el desarrollo. En este trabajo describimos la interdependencia de nueve rasgos florales en Mimulus luteus var. luteus (Phrymaceae), en un intento por caracterizar los módulos funcionales sobre los cuales la selección natural pudiera eventualmente actuar. Mediante análisis de desviación límite-excluyente detectamos cuatro módulos: (a) un módulo de atractividad floral, (b) un módulo de comportamiento estigmático, (c) un módulo de superficie estigmática, y (d) un módulo de hercogamia. Se discuten las consecuencias de estos hallazgos para futuros estudios de selección natural en esta especie.

Palabras clave: desviación limite-excluyente, evasión de la autopolinización, evolución correlacionada, integración fenotípica, interacción planta-polinizador.

\section{INTRODUCTION}

Most studies assessing the evolution of the floral phenotype have focused on particular rather than integrated floral traits (e.g., Johnston 1991, Johnson \& Steiner 1997, Maad 2000, Medel et al. 2003). Implicit in this approach is the assumption that phenotypic components do not influence each other through epigenetic and developmental pathways. Modular organization (modularity) refer at set of traits, functionally related, that present a hierarchically arrangement in living beings and can be recognize from cellular domains to group of individuals (Raff \& Raff
2000, West-Eberhard 2003). Consideration of the modular organization that characterizes most organisms has been recently incorporated into theoretical and empirical studies of natural selection (e.g., Armbruster 1990, Price \& Langen 1992, Murren et al 2002). This is in part, because modules often represent functionally integrated structures upon which natural selection can act to a greater extent than on particulate traits (Schlichting \& Pigliucci 1998, Raff \& Raff 2000, West-Eberhard 2003).

Flower attraction has been long associated with pollinator visits (e.g., Darwin 1878, Sprengel 1996). Many hermaphroditic plants exhibit attractive floral traits for pollinator 
species (e.g., Waser \& Price 1981, Dafni \& Kevan 1996, Jones \& Reithel 2001) and color patterns and nectar guide cues are known to increase the chance of flowers becoming visited by animal pollinators (Charlesworth \& Charlesworth 1987, Stanton et al 1991, Robertson et al. 1999, Lunau 2002, Ashman \& Morgan 2004). In spite of that, and even though early authors suggested that flower traits represent functionally related units (Berg 1959, 1960, Stebbins 1974), studies on the evolution of flower design from a modular perspective are relatively scarce in the literature (but see Herrera 2001, Herrera et al 2002, Murren et al. 2002). In this study, we intended to determine the modular structure of flowers of Mimulus luteus var. luteus L. (Linn. 1763), a herbaceous plant previously described to be target of pollinator-mediated selection (Medel et al. 2003). More specifically, we attempt to see some relation degree among the traits that constitute the flower, such could suggest a module, a group of trait functionally related (Berg 1960, Raff \& Raff 2000, Magwene 2001, for several examples see West-Eberhard 2003) following the next questions: (1) What is the correlation structure and morphological dependence of floral traits in this specie?, (2) Do correlation patterns reveal the existence of a modular structure in flowers of this species?

\section{MATERIAL AND METHODS}

Mimulus luteus var. luteus (Phrymaceae) is an outcrossing herbaceous plant that inhabits flood streams in the Andes Mountain Range, from III to XI Region in Chile (von Bohlen 1995). It produces solitary hermaphroditic flowers with yellow tubular corollas. The lower corolla lobe often exhibits a red spot that serves as nectar guide (Medel et al. 2003). Flowers remain open from 3.6 to 5.9 days on average depending if they are pollinated or not, respectively (Medel et al. 2003). Measurements of the flower phenotype were performed during February 2003 in a population located at El Yeso meadows $\left(33^{\circ} 37^{\prime} \mathrm{S}, 70^{\circ} 01^{\prime} \mathrm{W}, 2,580 \mathrm{~m}\right)$, Region Metropolitana, Chile. The population showed a high flower density (130-150 flowers $\mathrm{m}^{-2}$ ), distributed in a patch of $1,350 \mathrm{~m}^{2}$. Vegetation included Calceolaria biflora (Scrophulariaceae), Echium vulgare
(Borraginaceae), Stemodia chilensis (Scrophulariaceae) and Chuquiraga oppositifolia (Asteraceae) as the most common species. At the study site, M. luteus var. luteus was pollinated by the bumblebees Centris nigerrima (Anthophoridae), Bombus dalhbomi (Hymenopteridae), Bombus terrestris (Hymenopteridae), Megachile semirufa (Megachilidae) and the Andean hummingbird Oreotrochilus leucopleurus (Trochilidae). Even though nectar production in M. luteus is not associate with corolla and nectar guide size, flowers visited by insects have 1.25 -fold larger corollas and 1.72-fold larger nectar guides than the hummingbird visited species (Medel et al. 2003).

Using silk bags, we randomly bagged 200 flower buds from different individual plants and checked for flower opening in the next two days after bagging at early morning. Once in anthesis, we recorded the following characters: (a) stigma closing time (CT), as the time elapsed from contacting the lower stigma surface with a sterile pin up to the complete stigma closure, (b) stigma reopening time (RT), as the time elapsed from the moment of stigma closure to the moment stigma reopened completely their lobes up to the same angle before touching, (c) lower lobe stigma height $(\mathrm{SH})$, as the distance between the lower margin of the lobe to the division of the stigma, (d) lower lobe stigma width (SW), as the distance between the major axe of the lobe, (e) style height (ST), as the distance from the apex of the ovary to the tip, and (f) ovary length (OL), as the distance from the base to the apex of the ovary. Time measurements were performed using a chronometer (precision $0.01 \mathrm{sec}$ ). All distance measurements were performed with a digital calliper (precision $0.01 \mathrm{~mm}$ ). Because stigma behavior may be influenced by abiotic factors that vary during the day (Fetscher \& Kohn 1999), we recorded the time day at which measurements were performed; this variable was correlated with CT and RT. Morphological measurements were recorded from two sets of digital pictures on each corolla. We took pictures from the perspective of approaching pollinators, in a plane $90^{\circ}$ to the long axis of the corolla. A second set of pictures was taken from a lateral view, parallel to the corolla axis to describing the stigma. The distance from the camera objective to the flower was kept 
constant by using a rigid support. From digital pictures in the laboratory, we recorded corolla size (CS), nectar guide size (NGS), anther height (AH), and stigma aperture angle (AA), using UTHSCSA ImageTool for Windows, version 2.0 (University of Texas Health Science Centre, San Antonio, Texas, USA). Also, we indirectly measured two variables, the distance between stigmatic lobes (SD), this it was calculated using the function that describes the distance between two points in the perimeter of an $\operatorname{arch}\left(\mathrm{SD}=2 \cdot \pi \cdot \mathrm{AA} \cdot \mathrm{SH} \cdot 360^{-1}\right)$ and the herchogamy (HK), the distance between stigma surface and anthers. This last was calculated as the gineceum length (style plus ovary length) minus the anthers length. The descriptive statistics for all variables is presented in Table 1. We used ten traits to study the relationship degree among them (Table 2): CT, RT, ST, OL, SH, SW, AA, AH, $\mathrm{CS}$ and NGS. Some of these are depicted in Fig. 1. To avoid that repeated measures exist, we didn't include SD and HK in our analysis because these variables were indirectly measured.

To explore patterns of trait covariation, we used the notion of conditional independence developed by Magwene (2001). This notion consists on a quantitative characterization of modularity or morphological integration, or in other words, which traits are related and how strong is the correlation among traits indicative of integration. Basically, the Magwene's method build a correlation diagram among traits (traits are represented by letters $i$ or $j$ ), named independence graphs, and it is a graphical hypothesis that represent to us an arrangement of the measured characters (Fig. 2). Contrary to common methods based on correlation that assumes dependence among traits, this use a null hypothesis of independence of traits (Magwene 2001). First, we standardized all variables to have zero mean and unit variance (z-transformation) before analyses by subtracting the mean of the trait from each value and dividing by the standard deviation. We constructed a simple correlation matrix among all variables (Table 2), that was subsequently inverted (inverse matrix depicted as $\Omega=\Sigma^{-1}$ following the Magwene's nomenclature). In the inverse correlation matrix, each diagonal element $\left(\Omega_{\mathrm{ii}}\right)$ is related to the multiple correlation coefficient between the variable $i$ and all other variables $\left(\Omega_{\mathrm{ii}}=1 /(1-\right.$ $\mathrm{R}^{2}$ ), where $\mathrm{R}$ is the multiple correlation coefficient between variable $i$ and all

TABLE 1

Descriptive statistics of variables included in analyses. $\mathrm{n}$ is the number of flowers (each from a different plant). SE indicates 1 standard error

Estadística descriptiva de las variables incluidas en los análisis. $\mathrm{N}$ es el número de flores (de distintas plantas). SE indica 1 error estándar

\begin{tabular}{lccc}
\hline Variable & $\mathrm{n}$ & Mean (SE) & Range \\
\hline Stigma closure time $(\mathrm{sec})(\mathrm{CT})$ & 157 & $9.65(0.77)$ & $0.89-51.59$ \\
Stigma reopening time $(\mathrm{sec})(\mathrm{RT})$ & 167 & $788.3(32.1)$ & $8.1-2245.9$ \\
Stigma aperture angle $\left(^{\circ}\right)(\mathrm{AA})$ & 154 & $66.05(2.13)$ & $24.05-129.02$ \\
Stigma distance $(\mathrm{mm})(\mathrm{SD})$ & 150 & $3.17(0.12)$ & $1.01-6.92$ \\
Style height $(\mathrm{mm})(\mathrm{ST})$ & 154 & $18.98(0.15)$ & $12.28-24.12$ \\
Anther height $(\mathrm{mm})(\mathrm{AH})$ & 167 & $17.04(0.21)$ & $14.05-21.84$ \\
Herkogamy $(\mathrm{mm})(\mathrm{HK})$ & 136 & $2.85(0.19)$ & $0.06-7.71$ \\
Ovary length $(\mathrm{mm})(\mathrm{OL})$ & 154 & $9.39(0.10)$ & $5.76-12.92$ \\
Lower stigma lobe height $(\mathrm{mm})(\mathrm{SH})$ & 152 & $2.68(0.04)$ & $1.71-3.90$ \\
Lower stigma lobe wide $(\mathrm{mm})(\mathrm{SW})$ & 151 & $608.9(0.04)$ & $1.44-4.85$ \\
Corolla size $\left(\mathrm{mm}^{2}\right)(\mathrm{CS})$ & 142 & $18.67(2.98)$ & $280.3-962.3$ \\
Nectar guide size $\left(\mathrm{mm}^{2}\right)(\mathrm{NGS})$ & 142 & & $0-85.01$
\end{tabular}


variables). $\mathrm{R}^{2}$ ranges from 0 to $100 \%$ and represents the extent to which the trait can be predicted by the other traits in the matrix. If $\Omega$ is scaled to 1 on the diagonal, the off-diagonal elements of the resulting matrix are the negatives of the partial correlation coefficients given by all the other variables,

$$
\rho_{\mathrm{ij}} \cdot{ }_{\{\mathrm{K}\}}=\frac{-\Omega_{\mathrm{ij}}}{\sqrt{\left(\Omega_{\mathrm{ii}} \Omega_{\mathrm{jj}}\right)}}(2),
$$

The $\rho$ values estimate the strength of the relationship among variables (Magwene 2001). It is possible to calculate the edge exclusion deviance (EED) using the $\rho$ estimator that indicates whether a particular edge (or trait) from total edges $(\mathrm{K})$ can be eliminated from a complete model with all the possible connections between variables. The EED value can be calculated as,

$$
-\mathrm{N} \ln \left(1-\rho^{2}{ }_{\mathrm{ij}}{ }_{\{\mathrm{K}\}}\right)(3),
$$

where $\mathrm{N}$ is the number of individuals in the sample $\rho^{2}$ ij $_{-}\{\mathrm{K}\}$. The EED-value is tested using $\chi^{2}$-distribution with one degree of freedom (Whittaker 1990). The last step is to determinate the degree of edge strength between any pair of variables. Magwene (2001) suggested a method to estimate the degree of interdependence of any pair of traits $(\mathrm{i}, \mathrm{j})$ as $-0.5 \ln \cdot\left(1-\rho^{2}{ }_{\mathrm{ij}} \cdot\{\mathrm{K}\}\right)$. All statistical analyses were performed in STATISTICA v5.1 (Statsoft Inc. 1997).

\section{TABLE 2}

Correlation matrix among traits (Pearson correlation coefficients). All correlations presented statistically significance $(\mathrm{P}<0.05)$ after Bonferroni corrections except AH that didn't show interaction with any variable; $\Omega_{\mathrm{ii}}$ is related to the multiple correlation coefficient between variable $\mathrm{i}$ and all other variable; $\mathrm{R}^{2}$ represents the extent to which the trait can be predicted by the other traits in the matrix

Matriz de correlación entre los rasgos (coeficiente de correlación de Pearson). Todas las correlaciones presentaron significancia estadística $(\mathrm{P}<0,05)$ después de la corrección de Bonferroni, excepto AH que no mostró relación con ningún rasgo; $\Omega_{\text {ii }}$ está relacionado con el coeficiente de correlación múltiple entre una variable ('i') y todo el resto de las variables;

\begin{tabular}{|c|c|c|c|c|c|c|c|c|c|c|c|c|}
\hline Variable & $\mathrm{CT}$ & $\mathrm{RT}$ & ST & $\mathrm{OL}$ & $\mathrm{AH}$ & $\mathrm{SH}$ & SW & AA & $\mathrm{CS}$ & NGS & \multicolumn{2}{|c|}{$\Omega_{\mathrm{ii}} \mathrm{R}^{2}(\%)$} \\
\hline Closing time (CT) & 1.00 & & & & & & & & & & 0.46 & 0 \\
\hline Reopening time (RT) & 0.79 & 1.00 & & & & & & & & & -15.97 & 100 \\
\hline Style height (ST) & 0.36 & 0.46 & 1.00 & & & & & & & & -11.52 & 100 \\
\hline Ovary length (OL) & 0.36 & 0.46 & 1.00 & 1.00 & & & & & & & 5.44 & 81 \\
\hline Anther length (AH) & 0.04 & 0.21 & 0.01 & 0.05 & 1.00 & & & & & & 0.19 & 1 \\
\hline Lower lobe height (SH) & 0.32 & 0.42 & 0.95 & 0.95 & -0.12 & 1.00 & & & & & 32.99 & 97 \\
\hline Lower lobe width (SW) & 0.30 & 0.41 & 0.2 & 0.92 & 0.07 & 0.97 & 1.00 & & & & 20.85 & 95 \\
\hline Aperture angle (AA) & 0.49 & 0.61 & 0.34 & 0.35 & 0.06 & 0.33 & 0.35 & 1.00 & & & 0.28 & 0 \\
\hline Corolla size (CS) & -0.29 & -0.20 & -0.51 & -0.51 & -0.15 & -0.47 & -0.45 & -0.22 & 1.00 & & 50.26 & 98 \\
\hline Nectar guide size (NGS) & -0.29 & -0.20 & -0.51 & -0.51 & -0.08 & -0.47 & -0.45 & -0.22 & 1.00 & 1.00 & 50.26 & 98 \\
\hline
\end{tabular}
$\mathrm{R}^{2}$ representa la proporción por la cual un rasgo puede ser predicho por todo el resto de las variables presentes en la matriz 


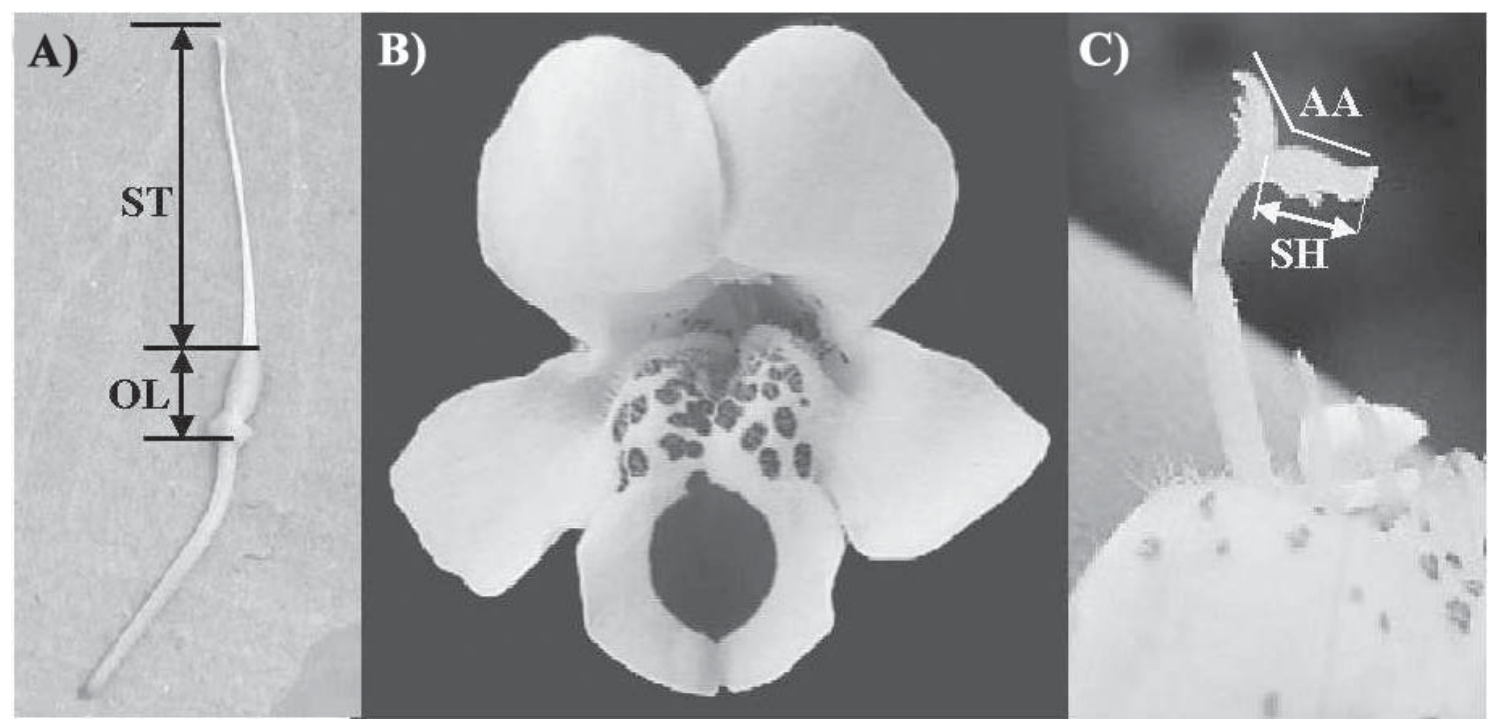

Fig. 1: Pictures that show some of the floral traits measured in M. luteus var. luteus; (A) gineceum, where the style length (ST) and ovary length (OL) was measured; (B) corolla and nectar guide; (C) stigma lobes aperture angle (AA) and lower stigma lobe height (SH).

Fotografías que muestran algunos de los rasgos florales medidos en M. luteus var. luteus; (A) gineceo, donde se midió el largo del estilo (ST) y la longitud del ovario (OL); (B) corola y guía de néctar; (C) ángulo de apertura de los lóbulos estigmáticos (AA) y altura del lóbulo estigmático inferior (SH).

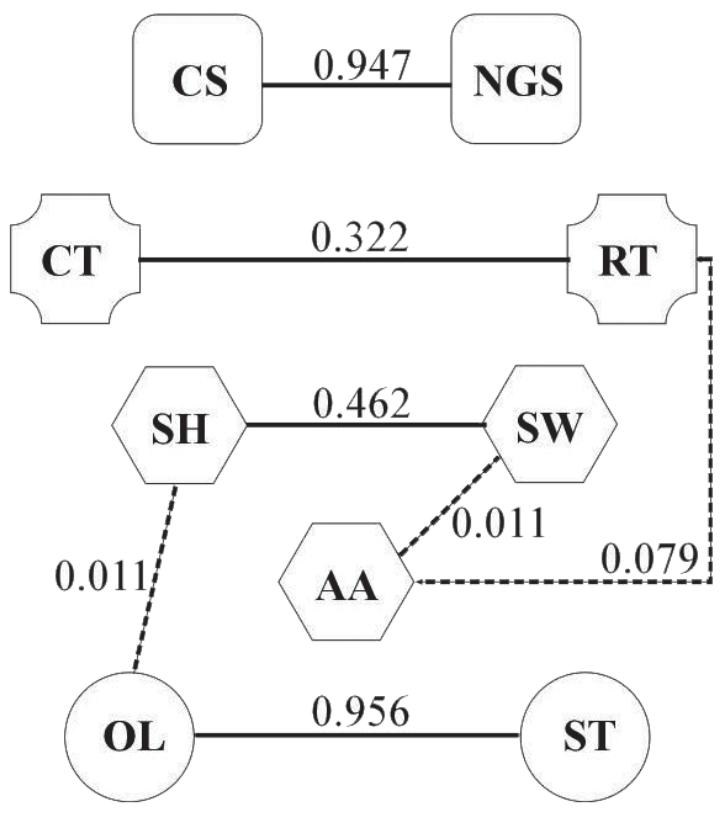

Fig 2: Independence graph that represents the relationships among floral traits in M. luteus var. luteus using conditional independence analysis (Magwene 2001). Solid lines indicate strong dependence and dashed lines represent weak dependence. Numbers represent the edge strength. Trait abbreviations as in Table 1.

Gráfico de independencia que representa las relaciones entre rasgos florales en M. luteus var. luteus obtenidas usando matrices de independencia condicional (Magwene 2001). Líneas sólidas indican alta dependencia y líneas punteadas reflejan una dependencia débil. Los números representan la fuerza de la interacción. Las abreviaciones de los caracteres se indican en la Tabla 1. 


\section{RESULTS AND DISCUSSION}

There was a high degree of overall correlation among nine of 10 evaluated traits as revealed by the pairwise correlation analysis (Table 2). Except by $\mathrm{AH}$, all correlations remained significant after correcting by the Bonferroni sequential tests (Rice 1989). The analysis of conditional dependence, however, revealed only four putative modules (Fig. 2). Excepting by closing time (CT), aperture angle (AA) and anther height $(\mathrm{AH})$ that could not be predicted by any other variable, all remaining variables showed a high degree of predictability from at least one other trait (Table 1, Fig. 2). The first putative module included traits related to attraction to pollinators (corolla and nectar guide size, $94.7 \%$ interdependence), these traits have been related with flower attractiveness to hummingbird and insect visits and nectar guide size presented a selective regime pollinator-mediated (Medel et al. 2003). If CS and NGS are related by interdependence graph and presented some degree of associate functionally (attractiveness upon pollinators), we could think in these as a module. The second putative module included traits related to stigma behavior (closing and reopening time, $32.2 \%$ interdependence). Interestingly, these traits have been suggested to avoid selfing (Richardson 2004), by the way of increasing pollen capture and growth of pollinic tubes (Fetscher \& Kohn 1999). Traits related to stigma behavior have evolved independently in at least three plant families including Martyniaceae, Bignoniaceae, and Phrymaceae, and stigma closure speed may represent a key trait that avoids selfpollination because it reduces stigma surface exhibition (Fetscher \& Kohn 1999). We didn't observe relation between $\mathrm{CT}$ and $\mathrm{RT}$ with the hours of day (CT: $\beta=-0.035, \mathrm{r}^{2}=0.052$, $\mathrm{F}_{[0.05,113]}=0.027 \mathrm{P}=0.966 ; \mathrm{RT}: \beta=0.441, \mathrm{r}^{2}$ $=0.064, \mathrm{~F}_{[0.05,137]}=0.136, \mathrm{P}=0.746$; values represent a regression summary for $\mathrm{CT}$ and RT as dependent variables), this result discards a dependence between stigma behaviour and some variable that co-varies with the hours of day. The association between CT and RT, could be explained as a module, since both traits are associated functionally with selfing avoidance. A third putative module included traits related to the stigma surface (stigma width and height, $46.2 \%$ interdependence). Stigma lobe size has been related to the amount of pollen that the plant receives (Wang \& Cruzan 1998, Thompson \& Dommée 2000). The fourth putative module included the relationship between ovary and style length (95.6\% interdependence), two traits used to characterization of gineceum. These traits don't present a clear related functionally, making difficult their determination as a module, however ST is a essential component of herkogamy (the stigma-anther separation).

Mimulus species present hermaphroditic and herkogamic flowers (Carr \& Fenster 1994) with traits associated to specific pollinator taxa (Schemske \& Bradshaw 1999, Medel et al. 2003). However, the most attractive flowers in hermaphroditic plants may have an increased chance of becoming self-pollinated because pollinators may deposit pollen into the stigma of the same visited flower (facilitated selfing, Charlesworth \& Charlesworth 1987, Ritland 1990, Dudash \& Ritland 1991, Lloyd \& Schoen 1992, Harder \& Barrett 1996, Fetscher \& Kohn 1999). Following Darwin (1878), many authors have suggested that the avoidance of selfing has been a major factor in floral trait evolution (Snow et al. 1996). For instance, several authors have suggested that anther-stigma separation (herkogamy) and stigma behavior could represent modules that avoid selfpollination in other species of Mimulus (Dudash \& Ritland 1991, Fetscher \& Kohn 1999). These antecedents permit us infer some degree of functionality in measured traits, necessary for included them in a module. Whether modules involved in the avoidance of selfing are selected and evolve in correlation with modules involved in pollinator attraction needs to be assessed in future studies of $M$. luteus.

\section{ACKOWLEDGMENTS}

This study was part of activities of the Center for Advanced Studies in Ecology and Research on Biodiversity funded by Milenio P02-051F ICM. Rodrigo Medel thanks the indirect support of Fondo Nacional de Desarrollo Científico y Tecnológico, FONDECYT 1010660. 


\section{LITERATURE CITED}

ARMBRUSTER WS (1990) Estimating and testing the shapes of adaptive surface: the morphology and pollination of Daleschampia blossoms. American Naturalist 135: 14-31.

ASHMAN T \& MT MORGAN (2004) Explaining phenotypic selection on plant attractive characters: male function, gender balance or ecological context? Proceedings of Royal Society of London B 271: 553-559.

BERG RL (1959) A general evolutionary principles underlying the origin of development homeostasis. American Naturalist 93: 103-105.

BERG RL (1960) The ecological significance of correlation pleiades. Evolution 14: 171-180.

CARR DE \& CB FENSTER (1994) Levels of genetic variation and covariation for Mimulus (Scrophulariaceae) floral traits. Heredity 72: 606618

CHARLESWORTH D \& B CHARLESWORTH (1987) The effect of the investment in attractive structures on allocation to male and female functions in plants. Evolution 41: 948-968.

DAFNI A \& PG KEVAN (1996) Floral symmetry and nectar guides: ontogenetic constrains from floral development, colour pattern and functional significance. Botanical Journal of Linnaean Society 120:371-377.

DARWIN C (1878) The different forms of flowers on plants of the same species. Murray, London United Kingdom. 352pp.

DUDASH MR \& K RITLAND (1991) Multiple paternity and self-fertilization in relation to floral age in Mimulus guttatus (Scrophulariaceae). American Journal of Botany 78: 1746-1753.

FETSCHER AE \& JR KOHN (1999) Stigma behaviour in Mimulus aurianticus (Scrophulariaceae). American Journal of Botany 86: 1130-1135.

HARDER LD \& SCH BARRETT (1996) Pollen dispersal and mating patterns in animal-pollinated plants. In: Lloyd DG \& SCH Barrett (eds) Floral biology: studies on floral evolution in animal-pollinated plants: 140-190. Chapman Hall, New York, New York, USA.

HERRERA CM (2001) Deconstructing a floral phenotype: Do pollinators select for corolla integration in Lavandula latifolia?. Journal of Evolutionary Biology 14: 574-584.

HERRERA CM, X. CERDÁ, MB GARCÍA, J GUITIÁN, M. MEDRANO, PJ REY \& AM SANCHEZLAFUENTE (2002) Floral integration, phenotypic covariance structure and pollinator variation in bumblebee-pollinated Helleborus foetidus. Journal of Evolutionary Biology 15: 108-121.

JOHNSON SD \& KE STEINER (1997) Long-tongued fly pollination and evolution for floral spur length in the Disa draconis complex (Orchidaceae). Evolution 51: 45-53.

JOHNSTON MO (1991) Natural selection on floral traits in two species of Lobelia with different pollinators. Evolution 45: 1468-1479.

JONES KN \& JS REITHEL (2001) Pollinator mediatedselection on a flower colour polymorphism in experimental populations of Anthirrinum (Scrophulariaceae). American Journal of Botany 88: 447-454.

LLOYD DG \& SCHOEN DJ (1992) Self- and crossfertilization in plants. I. Functional dimensions. International Journal of Plant Sciences 153: 358-369.
LUNAU K (2002) The evolution of flowering plants flowers visitors and interactions between them: at look at flower biology with G. Von Wahlert. Bonner Zoology Monographs (Germany) 50: 109136.

MAAD J (2000) Phenotypic selection in hawkmothpollinated Platanthera bifolia: targets and fitness surfaces. Evolution 54: 112-123.

MAGWENE PM (2001) New tools for studying integration and modularity. Evolution 55: 1734-1745.

MEDEL R, C BOTTO-MAHAN \& M KALIN-ARROYO (2003) Pollinator-mediated selection on the nectar guide phenotype in the Andean monkeyflower, Mimulus luteus. Ecology 84: 1721-1732.

MURREN CJ, N PENDLETON \& M PIGLIUCCI (2002) Evolution of phenotypic integration in Brassica (Brassicaceae). American Journal of Botany 89: 655-663.

PILSON D (2000) Herbivory and natural selection on flowering phenology in wild sunflower, Helianthus annuиs. Oecologia 122: 72-82.

PRICE T \& T LANGEN (1992) Evolution of correlated characters. Trends in Ecology and Evolution 7: $307-$ 310.

RAFF EC \& RAFF RA (2000) Dissociability, modularity, evolvability. Evolution and Development 2: 235 237.

RICHARDSON SC (2004) Benefits and costs of floral visitors to Chilopsis linearis; pollen deposition and stigma closure. Oikos 107: 363-375.

RICE WR (1989) Analyzing tables of statistical tests. Evolution 43: 223-225.

RITLAND K (1990) Inferences about inbreeding depression based upon changes of the inbreeding coefficients. Evolution 44: 1230-1241.

ROBERTSON AW, C MOUNTJOY, BE FAULKNER, MV ROBERTS \& MR MACNAIR (1999) Bumble bee selection of Mimulus guttatus flowers: the effects of pollen quality and reward depletion. Ecology 80: 2594-2606.

SCHEMSKE DW \& HD BRADSHAW Jr (1999) Pollinator preference and the evolution of floral traits in Monkeyflowers (Mimulus). Proceedings of the Natural Academy of Sciences USA 96: 1191011915

SCHLITCHING CD \& M PIGLIUCCI (1998) Phenotypic evolution: a reaction norm perspective. Sinauer Associates, Sunderland, Massachusetts, USA. 387 pp.

SNOW AA, TP SPIRA, R SIMPSON\& RA KLIPS (1996) The ecology of geitenogamous pollination. In: Lloyd DG \& SCH Barrett (eds) Floral biology: studies on floral evolution in animal-pollinated plants: 191-216. Chapman Hall, New York, New York, USA

SPRENGEL CK (1996) Discovery of the secret of nature structure and fertilisation of flowers. In: Lloyd DG \& SCH Barrett (eds) Floral biology: studies on floral evolution in animal-pollinated plants: 3-44. Chapman Hall, New York, New York, USA.

STANTON ML, HL YOUNG, NC ELLSTRAND \& JC CLEGG (1991) Consequences of floral variation for male and female reproduction in experimental populations of wild radish Raphanus sativus L. Evolution 45: 268-280.

STATSOFT (1997). STATISTICA for Windows. Tulsa, Oklahoma, USA. http://www.statsoft.com

STEBBINS (1974) Flowering plants. Evolution above the species level. Harvard University Press, Cambridge, Massachusetts, USA. 397 pp. 
THOMPSON JD \& B DOMMÉE (2000) Morph-specific patterns of variation in stigma height in natural populations of distylous Jasminun fruticans. New Phytologist 148: 303-314.

VON BOHLEN C (1995) El género Mimulus L. (Scrophuliareaceae) en Chile. Gayana Botánica 52: 7-28.

WANG J \& MB CRUZAN (1998) Interespecific mating in the Piriqueta caroliniana (Turneraceae) complex: effects of pollen load size and composition. American Journal of Botany 85: 1172-1179.

Associate Editor: Julio Gutiérrez

Received November 18, 2004; accepted May 9, 2005
WASER NM \& M PRICE (1981) Pollinator choice and stabilizing selection for flower colour in Delphinium nelsonii. Evolution35: 376-390.

WEST-EBERHARD (2003) Developmental plasticity and evolution. Oxford University Press, New York, USA. $791 \mathrm{pp}$.

WHITTAKER J (1990) Graphical models in applied mathematical multivariate statistics. John Wiley and Sons, New York, New York, USA. (cited in Magwene 2001) 